\title{
Students' perception of communication and collaboration effectiveness in online learning mathematics during the COVID-19
}

\author{
Sri Supiyati *, Muhammad Halqi, Ahmad Rasidi \\ Mathematics Education Study Program, Universitas Hamzanwadi, West Nusa Tenggara, Indonesia \\ *Correspondence: *sri.supiyati@ hamzanwadi.ac.id \\ (c) The Author(s) 2022
}

\begin{abstract}
This study aims to determine student perceptions of the effectiveness of communication and collaboration in online learning mathematics during the COVID-19 pandemic. This study was an ex-post-facto with an exploratory, descriptive approach. The sample of this study was 26 students of the Mathematics Education Study Program at the Universitas Hamzanwadi. The respondents of this study were 26 students of Mathematics Education at Hamzanwadi University, five males and 21 females, which were obtained using the convenience sampling technique. This research was conducted in the even semester of the 2020/2021 academic year. The instrument used is a closed questionnaire with answers that are degraded according to the Likert scale and validated by experts. The research data were analyzed descriptively and inferential statistics. The results showed that (1) the perception of mathematics education students was $>58 \%$ of students giving a negative response to every question about the effectiveness of communication and collaboration in online learning; (2) ineffective communication and collaboration in online learning with an average student perception score of 2.16; (3) there is a positive and significant relationship between communication and collaboration in online learning during the COVID-19 pandemic with a significance value of 0.000 which is smaller than the alpha test value of $0.05(<0.05)$; (4) the relationship of communication and correlation in online learning is strong or high with a correlation coefficient value of 0.677 .
\end{abstract}

Keywords: communication; collaboration; COVID-19; mathematics; online learning

Received: 29 November 2021 | Revised: 3 December 2021

Accepted: 24 December 2021 | Published: 6 January 2022 


\section{Introduction}

The world pandemic of COVID-19 has not ended yet and has changed the world community lifestyle in all different aspects. (Surbakti \& Pamungkas, 2021). In Indonesia, it is known as new-normal, where people carry out limited activities by adhering to a health protocol to avoid COVID-19 spread. On March 11, 2020, The World Health Organization declared COVID-19 a global pandemic. Since then, the world community has been active and collaborative in carrying out various preventive and curative activities in handling the COVID-19 pandemic (Kusumaningrum \& Wijayanto, 2020), such as tracing and testing COVID-19, isolation and quarantine, social distancing, physical distancing, wearing a mask and hand washing, travel limitation and also taking care of positive Covid-19 (Gultom \& Sitanggang, 2020; Kusumaningrum \& Wijayanto, 2020; Sadikin \& Hamidah, 2020). Muliadi, Mirawati, and Husnul (2021) elaborated that COVID-19 Spread is very fast in many countries; it forced every country to provide a fast response in each policy regarding health care and social care in individual, institution, community, local, national, and international.

This ongoing pandemic has had a significant impact on changes in education in Indonesia, where the learning system must be carried out online to minimize outdoor community activities. Online learning is a new system in Indonesia. Iswari (2021), in general, learning is conducted offline. However, the policy of renewing the face-to-face learning system into online learning (Anhusadar, 2020; Firman \& Rahayu, 2020), has been the best solution to ensure the learning activities are conducted COVID-19 pandemic (Muliadi, Mirawati \& Jannah, 2021). Learning activities are the main component in education, ensuring that they can be carried out continuously and adequately (Maulah et al., 2020). Education in Indonesia has been conducted using the online system during the COVID-19 pandemic, even though there are still shortcomings that must be continuously evaluated (Muliadi et al., 2021). According to Muliadi et al. (2021), online learning is less effective due to limited interaction, communication, and collaboration between lecturers and students (Surbakti \& Pamungkas, 2021).

During the current COVID-19 pandemic, the online learning system uses computer technology as an intermediary for communication between lecturers and students (Anugrahana, 2020). Putri and Irwansyah (2021) create a distance that separates lecturers and students; there is no direct interaction and collaboration but is only mediated by digital platforms. Online learning tends to be dominated by communication through text, audio, or video, so there is a distance between educators and students during the learning process emotionally (Muliadi et al., 2021). Febrianto et al. (2020) emphasized that most students cannot ignore the importance of a lecturer in front of the class to build interaction, communication, and collaboration in the learning process so that the learning communication process is more effective. Therefore, the success of the learning process depends on the effectiveness of the communication process between educators and students (Toharudin, 2020).

Online learning that utilizes digital platforms should not be an obstacle for students as the "z" generation is very close to digital technology. Buckingham (2013) explained that the 
current generation is a digital generation formed by new media technology. It suits the concept of Prensky (2009) that the young generation is famous as a digitally native generation, where they exist as the generation who has been adopting technology since they were born. However, as a digital generation, university students are not automatically able to adapt well in transforming conventional learning systems (face to face) to online systems. Therefore, lecturers and students must build an excellent relationship on learning interaction through communication and collaboration to achieve learning outcomes. Following Surbakti and Pamungkas (2021), online learning can be carried out properly if there is effective and maximum communication between lecturers and students. Sari et al. (n.d.) explained that learning communication is said to be good if students can understand the intent and purpose of the messages conveyed in learning to understand the material, generate interest in learning, and have good learning outcomes.

Student-lecturer communication is the key element in deciding the learning quality (Toharudin, 2020). The success of the learning process as a process of transforming educational messages is very dependent on the effectiveness of communication and collaboration between lecturers and students in learning interactions. The same thing must also be owned in online learning that uses information technology as a communication intermediary between lecturers and students (Anugrahana, 2020). However, there is no direct learning interaction and is only mediated by digital platforms (Toharudin, 2020). Therefore, lecturers are required to build "real" communication and collaboration in learning interactions with online systems. It is because, in today's online learning, students still think of lecturers as "teachers" who are essential to be able to explain in detail and comprehensively each learning material, so that communication and collaboration are determinants of the effectiveness of online learning (Febrianto et al., 2020).

Communication and collaboration have a significant role in online learning (Surbakti \& Pamungkas, 2021). Suranto (2005) explains that communication is an act of contact between the sender and the receiver. Through the message, the sender and receiver share experiences that give meaning to the message sent, received, and interpreted by the recipient. In the learning process, the design of information and the delivery of information in learning interactions will determine the quality of communication built between lecturers and students (Surbakti \& Pamungkas, 2021). Therefore, the effectiveness of online learning is largely determined by the quality of communication and collaboration built by lecturers and students through digital platforms. However, Putri and Irwansyah's (2021) research explains that computer-mediated communication cannot be implemented effectively due to internal, external, and contextual factors.

Online learning in the mathematic education study program of Universitas Hamzanwadi has been conducted since the Ministry of Education and Culture letter Number 3 of 2020 concerning Prevention of the Spread of COVID-19 in Education Units. Online learning in the COVID-19 pandemic, utilizing synchronous or asynchronous information technology (Muliadi et al., 2021). Muliadi et al. (2021) explained that the current digitalization era facilitates the implementation of online learning because of its fast advances in information 
and communication technology. At the beginning of the COVID-19 pandemic, online learning was an unfamiliar learning system, so lecturers were required to be adaptive by increasing creativity, skills, and professionalism (Maulah et al., 2020; Pangondian et al., 2019). Online learning is not limited to time and place by using technology in an open, flexible, and distributed learning environment (Putra et al., 2020). In online learning, lecturers do not just transfer materials and assignments through digital platforms but must remain competency-oriented (Kusumaningrum \& Wijayanto, 2020) and involve pedagogical, psychological, and didactic aspects (Mulyasa, 2013). Therefore, online learning is still through some steps, namely planning, implementation, assessment, and face-to-face learning. (Muliadi et al., 2021).

The effectiveness of communication and collaboration in online learning in the Mathematics Education Study Program needs to be evaluated to determine the level of achievement of the learning objectives set. Rohmawati (2015) explains that the effectiveness of online learning can be evaluated from learning interactions (communication and collaboration) and student mastery of learning materials. It is confirmed by Nugroho (2015) that the effectiveness of online learning is not only measured by the achievement of learning outcomes but also in terms of learning interactions and supporting facilities. Student responses or perceptions are essential indicators for effective communication and collaboration in online learning (Muliadi et al., 2021; Nugroho, 2015). Perception is the process of interpreting the stimulus received through the five senses to be processed into an understanding (Zhafira et al., 2020). Therefore, a study is needed to determine the perceptions of students of the Mathematics Education Study Program about the effectiveness of communication and collaboration in online learning during the COVID-19 pandemic.

\section{Methods}

This study was ex-post-facto research with an exploratory, descriptive approach (Muliadi et al., 2020; Muliadi et al., 2021). This study uses the ex-post-facto method to examine causal relationships that are not manipulated or treated by researchers, but researchers only record data from activities that have occurred. (Singarimbun, 2006). Descriptive exploratory studies are used to describe students' perceptions of the effectiveness of communication and collaboration activities in mathematics online learning during the COVID-19 pandemic (Muliadi et al., 2021). Applications used by lecturers of the Mathematics Education Study Program at Universitas Hamzanwadi in the even semester of the academic year 2020/2021 are WhatsApp and e-learning (LMS). The respondents of this study were 26 students (5 males and 21 females), which were obtained using the convenience sampling technique due to considering the accessibility of respondents in filling out online questionnaires during the COVID-19 pandemic (Fink, 2011).

The research instrument used was a closed questionnaire with answers to students' degraded perceptions based on the Likert scale (Muliadi \& Mirawati, 2020). This questionnaire was developed into several indicators regarding communication and 
collaboration in online learning systems. This research questionnaire is compiled in 8 statement points regarding the indicators developed by Adijaya and Santosa (2018) and has been validated by experts and declared valid. The indicators for the questionnaire developed are presented in Table 1 below.

Table 1. Indicator research instrument

\begin{tabular}{clcc}
\hline Component & \multicolumn{1}{c}{ Indicator } & Statement & Value \\
\hline Communication & $\begin{array}{l}\text { Communication between students and } \\
\text { lecturer }\end{array}$ & Negatif & 1 \\
\cline { 2 - 4 } & Communication between students & Negatif & 2 \\
\cline { 2 - 4 } & Expressing opinion and questions & Positif & 3 \\
\cline { 2 - 4 } & Elaborating concept/material & Positif & 4 \\
\hline Collaboration & Interaction between students and lecturer & Positif & 5 \\
\cline { 2 - 4 } & Interaction between students & Negatif & 7 \\
\cline { 2 - 4 } & $\begin{array}{l}\text { Discussion and collaboration between } \\
\text { students and lecture }\end{array}$ & Negatif & 8 \\
\cline { 2 - 4 } & $\begin{array}{l}\text { Discussion and collaboration between } \\
\text { students }\end{array}$ & & 6 \\
\hline
\end{tabular}

The research data were analyzed using descriptive statistics and inferential statistics. The statistical analysis used was the relative percentage and central tendency in the mean (mean score). Descriptive statistics were used to describe the perception data of mathematics education students about the effectiveness of communication and collaboration activities in online learning systems during the COVID-19 pandemic. The average student perception score is converted into categories as presented in Table 2 below.

Table 2. Interpretaion of average score of students' preception

\begin{tabular}{cc}
\hline Average score & Interpretation \\
\hline $3,51-4,00$ & Very good \\
$2,51-3,50$ & good \\
$1,51-2,50$ & fair \\
$1,00-1,50$ & Bad \\
\hline
\end{tabular}

Inferential statistical analysis was used to determine the relationship between student perceptions of communication activities (X) and collaborative activities (Y) in online learning mathematics. The analytical technique used is the product-moment correlation test (rxy) at a significance level of $5 \%(\alpha=0.05)$, with the formulation of a statistical hypothesis, namely $\mathrm{H} 0$ : There is no relationship between communication activities and collaborative activities in online learning mathematics) and H1: There is a relationship between communication activities and collaborative activities in online learning mathematics). If the results of the analysis are significant or the p-value of the correlation test is less than 0.05 , then $\mathrm{H} 0$ is rejected and $\mathrm{H} 1$ is accepted or vice versa. To interpret the correlation index value between the variables $\mathrm{X}$ and $\mathrm{Y}$, the conversion is used as presented in Table 3 below.

Table 3. Correlation coefficient interpretation (Muliadi, 2020)

\begin{tabular}{cc}
\hline Correlation Coefficient (r) & Interpretation \\
\hline $0.00-0.199$ & Correlation very weak or very low \\
$0.20-0.399$ & Correlation weak or low \\
$0.40-0.599$ & Correlation fair or enough
\end{tabular}




\begin{tabular}{cc}
\hline Correlation Coefficient $(\mathbf{r})$ & Interpretation \\
\hline $0.60-0.799$ & Correlation strong or high \\
$0.80-1.00$ & Correlation very strong or very high \\
\hline
\end{tabular}

\section{Results}

This study indicates that the description of students' perception data of communication and collaboration activities in online learning mathematics is presented in the form of percentages (see Table 4). There are four choices for each statement item, namely Strongly Agree (SS), Agree (S), Disagree (KS), or Disagree (TS).

Table 4. Description of students' perception

\begin{tabular}{|c|c|c|c|c|c|}
\hline \multirow{2}{*}{ No } & \multirow{2}{*}{ Statement } & \multicolumn{4}{|c|}{ Students' perception } \\
\hline & & SS & $\mathbf{S}$ & KS & TS \\
\hline 1 & $\begin{array}{l}\text { Communication between lecturers and students is less effective in } \\
\text { online learning mathematics }\end{array}$ & $15 \%$ & $54 \%$ & $31 \%$ & $0 \%$ \\
\hline 2 & $\begin{array}{l}\text { Communication between lecturers and students is less effective in } \\
\text { online learning mathematics }\end{array}$ & $8 \%$ & $50 \%$ & $42 \%$ & $0 \%$ \\
\hline 3 & $\begin{array}{l}\text { Expressing opinions and questions is more convenient in online } \\
\text { learning mathematics }\end{array}$ & $4 \%$ & $27 \%$ & $54 \%$ & $15 \%$ \\
\hline 4 & $\begin{array}{l}\text { Easier and faster elaboration of concepts/materials in online system } \\
\text { mathematics learning }\end{array}$ & $7 \%$ & $8 \%$ & $58 \%$ & $27 \%$ \\
\hline 5 & $\begin{array}{l}\text { Interaction between lecturers and students is less effective in online } \\
\text { learning mathematics }\end{array}$ & $7 \%$ & $31 \%$ & $54 \%$ & $8 \%$ \\
\hline 6 & $\begin{array}{l}\text { Interaction between lecturers and students is less effective in online } \\
\text { learning mathematics }\end{array}$ & $0 \%$ & $23 \%$ & $65 \%$ & $12 \%$ \\
\hline 7 & $\begin{array}{l}\text { Discussion and Collaboration between between lecturers and } \\
\text { students is less effective in online learning mathematics }\end{array}$ & $8 \%$ & $69 \%$ & $23 \%$ & $0 \%$ \\
\hline 8 & $\begin{array}{l}\text { Discussion and Collaboration between between lecturers and } \\
\text { students is less effective in online learning mathematics }\end{array}$ & $15 \%$ & $69 \%$ & $16 \%$ & $0 \%$ \\
\hline
\end{tabular}

Based on Table 4 above, it is known that most (69\%) students gave a negative response to statement number $1 ; 58 \%$ of students gave a negative response to statement number $2 ; 69 \%$ of students gave a negative response to statement number $3 ; 62 \%$ of students gave a negative response to statement number $4 ; 79 \%$ of students gave a negative response to statement number $5 ; 77 \%$ of students gave a negative response to statement number $6 ; 84 \%$ of students gave a negative response to statement number 7 ; and $85 \%$ of students gave a negative response to statement number 8 . The description of student perception data is emphasized in the form of a histogram in Figure 1 below. 


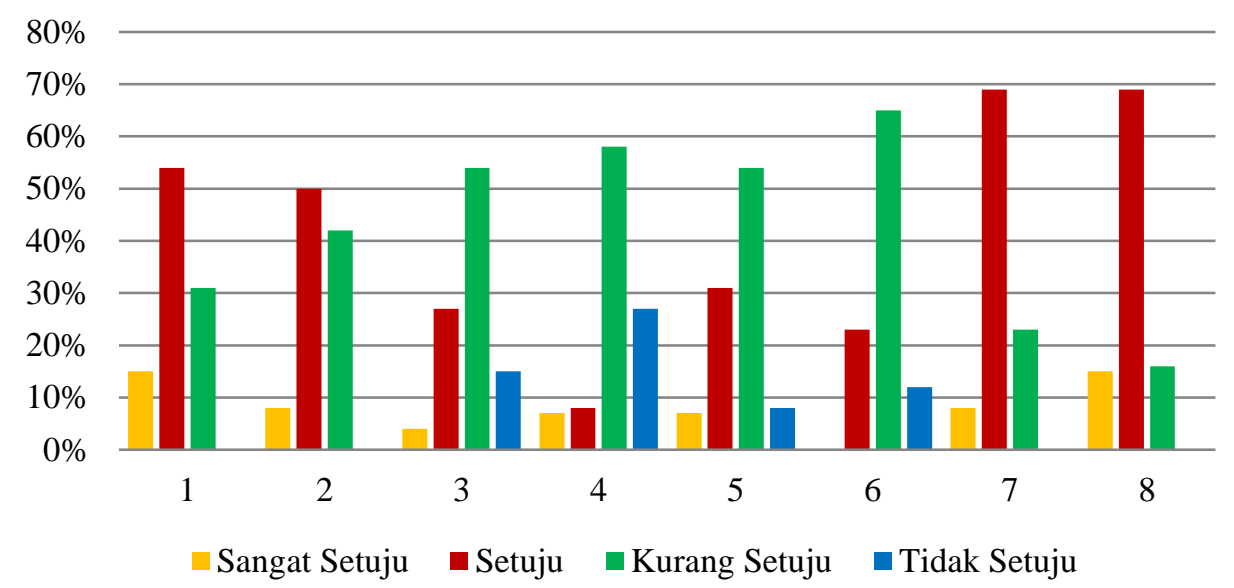

Figure 1. Percentage on students' perception on each question

Data on students' perceptions of mathematics education about communication and collaboration activities in online mathematics learning during the COVID-19 pandemic, were analyzed descriptively with a central tendency in the form of the mean (average). The results of the analysis are presented as presented in Table 5 below.

Table 5. Analysis result of central tendecy

\begin{tabular}{lc}
\hline \multicolumn{1}{c}{ Variance } & Value \\
\hline Number of students & 26 \\
Number of & 8 \\
Total score & 450 \\
Total average of & 56.25 \\
Deviation standard & 0.612 \\
Average score & $\mathbf{2 . 1 6}$ \\
Category & Pretty good \\
\hline
\end{tabular}

Based on the results of data analysis in Table 5 above, it is known that the average student perception score is still low. It is 2.16 with a pretty good category. The results of this study explain that mathematics education students justify ineffective communication and collaboration activities in online mathematics learning during the COVID-19 pandemic.

Students' perceptions of mathematics education regarding communication and collaboration activities were analyzed using the product-moment correlation test to determine the relationship between the effectiveness of communication and collaboration activities in online mathematics learning during the COVID-19 pandemic. The results of the productmoment correlation test (rxy) on the relationship between communication and collaboration activities in online learning mathematics are presented in Table 6 below.

Table 6. Correlation test product-moment $\left(\mathrm{r}_{\mathrm{xy}}\right)$

\begin{tabular}{cccc}
\hline Variance & Correlation Coefficient & N & Sig. (2-tailed) \\
\hline Communication - Collaboration & $\mathbf{0 . 6 7 7}$ & 26 & 0.000 \\
\hline
\end{tabular}

Based on Table 6 above, it is known that the correlation coefficient value of 0.677 with a significance value of 0.000 is smaller than the alpha test value of $0.05(<0.05)$. So H0 is rejected, and $\mathrm{H} 1$ is accepted, which means a positive and significant relationship between 
communication activities and collaborative activities in learning interactions in online learning during the COVID-19 pandemic. The correlation coefficient value is 0.677 , which means the relationship is strong or high.

\section{Discussion}

The results' elaboration of this study shows that communication and collaboration in online learning mathematics are not effective. It can be caused by many factors, such as the readiness of lecturers, students' facilities, and the learning environment to properly support online learning implementation (Sabrun et al., 2021). A good preparation stage is needed to provide learning media, online learning resources, support facilities, and a learning environment to achieve effective learning interactions (communication and collaboration). According to the opinion of Muliadi et al. (2021), online system learning requires maximum effort and support from all parties, including lecturers, families, and supporting facilities. The study results revealed that students recognized the importance of the learning environment in the effectiveness of online learning. Therefore, educators and families must create an integrative learning environment and fulfill various essential components of learning, which are discursive, adaptive, interactive, and reflective (Oktavian \& Aldya, 2020; Ulfah, 2020).

Implementing online learning during the COVID-19 pandemic requires sufficient time so that lecturers and students can adapt comprehensively. Putri and Irwansyah (2021) explained that distance in online learning is a determining factor because the absence of lecturers and students in learning interactions in class results in the loss of non-verbal communication (body language) and collaboration, thus affecting students' understanding of learning materials and learning interactions are also changing. During the current COVID-19 pandemic, the online learning system uses computer technology as an intermediary for communication between lecturers and students (Anugrahana, 2020). Putri and Irwansyah (2021) create a distance between lecturer and students, with no interaction and direct collaboration, but through digital platform media. Online learning tends to dominate via text, audio, or video so that it builds a distance between lecturer and students emotionally during the learning process (Muliadi et al., 2021). Febrianto et al. (2020) emphasize that most students cannot replace the lecturer's presence in front of the classroom to build interaction, communication, and collaboration in the learning process to achieve more effective online learning. Therefore, the success of the learning process is very dependent on the effectiveness of the communication process between educators and learners (Toharudin, 2020).

The percentage of students' negative responses thinks that online learning is ineffective because of limited interaction such as presenting opinions, discussion, collaboration, feedback, and response. It results in low mastery of learning materials due to limited communication and collaboration during online learning; even students admit that there is miscommunication between lecturers and students or between students. The effectiveness of online learning is measured by the achievement of student learning outcomes and the interactive process, and its supporting facilities (Nugroho, 2015). According to Sadikin and 
Hamidah (2020), online learning has unique challenges because of the location of students and lecturers who are far apart, so that lecturers cannot interact, guide, and directly supervise student activities during the learning process. (Szpunar et al., 2013) stated that students often have a wild imagination during online learning compared to face-to-face lectures. It is emphasized by the research result of (Sadikin \& Hamidah, 2020) that many students have difficulty understanding the lecture material given online. Students admit that independent materials and assignments are not enough because they need direct explanations from the lecturer (Swan, 2002).

This research explained the relationship between communication and collaboration in learning interaction. Learning interactions are built from communication and collaboration between lecturers and students so that communication and collaboration activities become a unified process in learning interactions. There is certainly communication and collaboration in online learning because there is the interaction of lecturers and students through digital platforms. Communication will be successful if there is good collaboration between the sender of information (lecturers) and recipients (students) (Iswari, 2021). However, in online learning, lecturers have a little difficulty ensuring that students' information is following what the lecturer expects. According to Rakhmat (2005), the psychology of effective communication is characterized by an increase in collaboration and interaction between both sides.

Communication and collaboration are integral processes in learning interactions, and they become important factors that determine the effectiveness of online learning. It follows the opinion of Toharudin (2020) that communication between lecturers and students is an essential factor determining the quality of online learning.

The success of the learning process as a process of transforming educational messages is very dependent on the effectiveness of communication and collaboration between lecturers and students (Anugrahana, 2020). Lecturers are required to build "real" communication and collaboration in learning interactions via online systems. In today's online learning, students still regard lecturers as "teachers" who are essential to explain in detail and comprehensively each learning material so that communication and collaboration become determining factors for the effectiveness of online learning (Febrianto et al., 2020). Communication and Collaboration have an important role in online learning and daily life (Surbakti \& Pamungkas, 2021). Communication and collaboration are two of seven skills of the 21 st Century which hold a crucial role in life (Wagner, 2010). Therefore, the effectiveness of online learning is largely determined by the quality of communication and collaboration built by lecturers and students through digital platforms.

\section{Conclusion}

The perception of mathematics education students is $>58 \%$ giving a negative response to every question about the effectiveness of communication and collaboration in online learning. Communication and collaboration in ineffective online learning with an average student 
perception score is relatively low about 2.16. There is a positive and significant relationship between communication and collaboration in online learning during the COVID-19 pandemic with a significance value of 0.000 , which is smaller than the alpha test value of $0.05(<0.05)$. The relationship between communication and correlation in online learning is strong or high, with a correlation coefficient of 0.677 .

\section{Conflicts of Interest}

The authors state that the publication of this work does not include any conflicts of interest. Furthermore, the writers have comprehensively addressed ethical issues such as plagiarism, misconduct, data fabrication and/or falsification, multiple publishing and/or submission, and redundancy.

\section{References}

Adijaya, N. \& Santosa, L. P. (2018). Persepsi mahasiswa dalam pembelajaran online [Student perception in online learning]. Jurnal Wanastra, 10(2), 105-110. https://doi.org/10.31294/w.v10i2.3931

Anhusadar, L. O. (2020). Persepsi mahasiswa PIAUD terhadap kuliah online di masa pandemi COVID-19 [PIAUD students' perceptions of online lectures during the COVID-19 pandemic]. KINDERGARTEN: Journal of Islamic Early Childhood Education, 3(1), 44-58. https://doi.org/10.24014/kjiece.v3i1.9609

Anugrahana, A. (2020). Hambatan, solusi dan harapan: Pembelajaran daring selama masa pandemi COVID-19 oleh guru sekolah dasar [Barriers, solutions and hopes: Online learning during the COVID-19 pandemic by primary school teachers]. Scholaria: Jurnal Pendidikan dan Kebudayaan, 10(3), 282-289. https://doi.org/10.24246/j.js.2020.v10.i3.p282-289

Buckingham, D. (2016). Making sense of the 'digital generation': Growing up with digital media. Self \& Society: An International Journal for Humanistic Psychology, 40(3), 715. https://doi.org/10.1080/03060497.2013.11084274

Daheri, M., Juliana, Deriwanto \& Amda, A. D. (2020). Efektivitas WhatsApp sebagai media belajar daring [The effectiveness of WhatsApp as an online learning medium]. Jurnal Basicedu, 4(4), 775-783. https://doi.org/10.31004/basicedu.v4i4.445

Febrianto, P. T., Mas'udah, S., \& Megasari, L. A. (2020). Implementation of online learning during the COVID-19 pandemic on Madura Island, Indonesia. International Journal of Learning, Teaching and Educational Research, 19(8), 233-254. https://doi.org/10.26803/ijlter.19.8.13

Firman, F., \& Rahayu, S. (2020). Pembelajaran online di tengah pandemi COVID-19 [Online learning in the midst of the COVID-19 pandemic]. Indonesian Journal of Educational Science (IJES), 2(2), 81-89. https://doi.org/10.31605/ijes.v2i2.659

Fink, A. (2011). How to sample in surveys. In how to sample in surveys (2nd edition). SAGE Publication.

Gultom, C. R. \& Sitanggang, S. G. M. (2020). Persepsi mahasiswa Unika terhadap kuliah online di masa pandemi COVID-19 [Unika students' perceptions of online lectures during the COVID-19 pandemic]. Jurnal Pendidikan Bahasa Indonesia dan Sastra (PEDISTRA), 3(1), 6-15. https://doi.org/10.54367/pendistra.v3i1.771 
Iswari, F. (2021). Komunikasi efektif dalam pembelajaran daring pada masa pandemi COVID-19 [Effective communication in online learning during the COVID-19 pandemic]. GANDIWA: Gagasan, Media dan Wacana, 1(1), 35-43. https://doi.org/10.54371/jiepp.v1i1.78

Kusumaningrum, B. \& Wijayanto, Z. (2020). Apakah pembelajaran matematika secara daring efektif? (Studi kasus pada pembelajaran selama masa pandemi COVID-19) [Is learning mathematics online effective? (Case study on learning during the COVID-19 pandemic)]. Kreano: Jurnal Matematika Kreatif-Inovatif, 11(2), 136-142.

Maulah, S., Nurul, F. \& Ummah, N. R. (2020). Persepsi mahasiswa biologi terhadap perkuliahan daring sebagai sarana pembelajaran selama pandemi COVID-19 [Biology students' perceptions of online lectures as a learning tool during the COVID-19 pandemic]. ALVEOLI: Jurnal Pendidikan Biologi, 1(2), 49-61. https://doi.org/10.35719/alveoli.v1i2.6

Muliadi, A., Prayogi, S., Bahalwan, F., Nirmala, W. \& Verawati, N. N. S. P. (2021). Online learning during the COVID-19 pandemic: Preservice teacher's perception. Jurnal Penelitian Pendidikan IPA, 7(3), 464-467. https://doi.org/10.29303/jppipa.v7i3.787

Muliadi, A., Mirawati, B. \& Jannah, H. (2021). Efektivitas pembelajaran daring di masa pandemi COVID-19: Persepsi mahasiswa pendidikan biologi [The effectiveness of online learning during the COVID-19 pandemic: Biology education student perceptions]. Jurnal Ilmu Sosial dan Pendidikan, 5(2), 625-633. https://doi.org/10.36312/jisip.v5i2.2020

Muliadi, A., Mirawati, B. \& Prayogi, S. (2021). The effect enterpreneurship education and subjective norm on biology students' self-efficacy in enterpreneurial. Prisma Sains: Jurnal Pengkajian Ilmu dan Pembelajaran Matematika dan IPA IKIP Mataram, 9(1), 127-135. https://doi.org/10.33394/jps.v9i1.3981

Muliadi, A. (2020). Sikap entrepreneur mahasiswa pendidikan biologi [Entrepreneurial attitude of biology education students]. Jurnal Ilmu Sosial dan Pendidikan, 4(3), 286291. https://doi.org/10.36312/jisip.v4i3.1208

Muliadi, A. \& Mirawati, B. (2020). The impact of personal attitude and subjective norm on entrepreneurial interest of biological education students. E-Saintika: Jurnal Penelitian dan Pengkajian Ilmu Pendidikan, 4(3), 342-351. https://doi.org/10.36312/esaintika.v4i3.307

Muliadi, A., Asri, I. H. \& Lestarini, Y. (2020). Efek pengetahuan dan lingkungan keluarga terhadap sikap entrepreneur mahasiswa [The effect of knowledge and family environment on student entrepreneurial attitudes]. Educatio: Jurnal Ilmu Kependidikan, 15(2), 125-137. https://doi.org/10.29408/edc.v15i2.2836

Mulyasa, E. (2013). Pengembangan dan implementasi kurikulum 2013 [2013 curriculum development and implementation]. Remaja Rosadakarya.

Nugroho, S. (2012). Profesionalisme guru SD negeri se-kecamatan Warungasem Kabupaten Batang: Suatu tinjauan aspek persepsi guru tentang kepemimpinan kepala sekolah dan motivasi berprestasi guru [Professionalism of public elementary school teachers in the district of Warungasem Batang Regency: A review of aspects of teacher perceptions about principal leadership and teacher achievement motivation]. Jurnal VARIDIKA, 24(2), 135-146. https://doi.org/10.23917/varidika.v24i2.710

Oktavian, R., \& Aldya, R. F. (2020). Efektivitas pembelajaran daring terintegrasi di era pendidikan 4.0 [The effectiveness of integrated online learning in the 4.0 education era]. Didaktis: Jurnal Pendidikan dan Ilmu Pengetahuan, 20(2), 129-135. https://doi.org/10.30651/didaktis.v20i2.4763

Pangondian, R. A., Santosa, P. I., \& Nugroho, E. (2019). Faktor-faktor yang mempengaruhi kesuksesan pembelajaran daring dalam revolusi industri 4.0 [Factors influencing the 
success of online learning in the industrial revolution 4.0]. Seminar Nasional Teknologi Komputer \& Sains (SAINTEKS), 1(1), 56-60. https://www.prosiding.seminarid.com/index.php/sainteks/article/view/122

Pratiwi, E. W. (2020). Dampak COVID-19 terhadap kegiatan pembelajaran online di sebuah perguruan tinggi kristen di Indonesia [The impact of COVID-19 on online learning activities at a Christian college in Indonesia]. Perspektif Ilmu Pendidikan, 34(1), 1-8. https://doi.org/10.21009/PIP.341.1

Prensky, M. (2009). H. sapiens digital: From digital immigrants and digital natives to digital wisdom. Innovate: Journal of Online Education, 5(3), Article 1.

Putra, E. A., Sudiana, R., \& Pamungkas, A. S. (2020). Pengembangan smartphone learning management system (S-LMS) sebagai media pembelajaran matematika di SMA [Development of smartphone learning management system (S-LMS) as a medium for learning mathematics in high school]. Kreano. Jurnal Matematika Kreatif-Inovatif, 11(1), 36-45. https://doi.org/10.15294/kreano.v11i1.21014

Putri, A. N. A. \& Irwansyah. (2021). Efektivitas komunikasi dalam pembelajaraan online [Effectiveness of communication in online learning]. Jurnal Teknologi dan Informasi Bisnis, 3(1), 54-63. https://doi.org/10.47233/jteksis.v3i1.184

Rakhmat, J. (2007). Psikologi komunikasi (edisi revisi) [Psychology of communication (revised edition)]. Remaja Rosdakarya

Rohmawati, A. (2015). Efektivitas pembelajaran [Learning effectiveness]. Jurnal Pendidikan Usia Dini, 9(1), 15-32.

Sabrun, Muliadi, A. \& Muhali. (2021). Pembelajaran matematika berbasis daring di masa pandemi COVID-19: Efektifkah? [Online-based mathematics learning during the COVID-19 pandemic: Is it effective?] Jurnal Ilmiah IKIP Mataram, 8(1). 175-188.

Sadikin, A. \& Hamidah, A. (2020). Pembelajaran daring di tengah wabah COVID-19 [Online learning in the midst of the COVID-19 outbreak]. BIODIK: Jurnal Ilmiah Pendidikan Biologi, 6(2), 214-224. https://doi.org/10.22437/bio.v6i2.9759

Saifuddin, M. F. (2017). E-learning dalam persepsi mahasiswa [E-learning in student $\begin{array}{llll}\text { perception]. Jurnal Varia Pendidikan, } & \text { 29(2), }\end{array}$ https://doi.org/10.23917/varidika.v29i2.5637

Singarimbun, M. \& Efendi, S. (2006). Metode penelitian survai (edisi revisi) [Survey research method (revised edition)]. Pustaka LP3ES Indonesia.

Soedarsono, Sari, \& Rina. (2019). Komunikasi pembelajaran guru PAUD dalam pembentukan karakter anak (Studi deskriptif komunikasi pembelajaran pada kegiatan belajar mengajar di PAUD Lembah Madu, Cimahi) [PAUD teacher learning communication in the formation of children's character (Descriptive study of learning communication in teaching and learning activities at PAUD Lembah Madu, Cimahi)]. JIKA (Jurnal Ilmu Komunikasi Andalan), 2(2), 75-94.

Suranto, A. W. (2005). Komunikasi perkantoran: Prinsip komunikasi untuk meningkatkan kinerja perkantoran [Office communication: Communication principles to improve office performance]. Media Wacana.

Surbakti, K. B. \& Pamungkas, I. N. A. (2021). Komunikasi melalui learning management system selama pembelajaran daring di Telkom University Bandung (Studi kualitatif pada mahasiswa rumpun ilmu sosial dan humaniora Telkom University Bandung) [Communication through the learning management system during online learning at Telkom University Bandung (Qualitative study on students from the social sciences and humanities group at Telkom University Bandung)]. Jurnal Dinamika Pendidikan, 14(2), $33-45$. 
Szpunar, K. K., Moulton, S. T., \& Schacter, D. L. (2013). Mind wandering and education: From the classroom to online learning. Frontiers in Psychology, 4, Article 495. https://doi.org/10.3389/fpsyg.2013.00495

Swan, K. (2002). Building learning communities in online courses: The importance of interaction. Education, Communication \& Information, 2(1), 23-49. https://doi.org/10.1080/1463631022000005016

Toharudin, M. (2020). Komunikasi dalam pembelajaran di era pandemi COVID-19 [Communication in learning in the era of the COVID-19 pandemic]. Prosiding Seminar Nasional FIP 2020, 238 - 248.

Ulfah, Y., \& Suryantoro, A. (2020). Studi awal tentang penggunaan media daring selama pandemi corona di SMPN Purworejo Lampung Tengah [Preliminary study on the use of online media during the corona pandemic at SMPN Purworejo, Central Lampung]. Al Jahiz: Journal of Biology Education Research, 1(1), 34-43. https://ejournal.metrouniv.ac.id/index.php/Al-Jahiz/article/view/2046

Wagner, T. (2010). Overcoming the global achievement gap (online). Harvard University.

Zhafira, N. H., Ertika, Y. \& Chairiyaton. (2020). Persepsi mahasiswa terhadap perkuliahan daring sebagai sarana pembelajaran selama masa karantina COVID-19 [Student perceptions of online lectures as a learning tool during the COVID-19 quarantine period]. Jurnal Bisnis dan Kajian Strategi Manajemen, 4(1), 37-45. 